there may be many countries in which working physicists are not adequately represented by national societies. Because of the great diff rences of size among the national societies - the British Institute of Physics and Physical Society, as it calls itself, is the largest-subscriptions will be paid on a non-linear scale by means of which a member society will pay an amount which is roughly inversely proportional to the square root of its size. As yet, there are no plans for launching a series of European physics journals (although there will be a newsletter fairly soon), but a sub-committee is hard at work on this part of the problem. The pattern of meetings and exchanges which the society hopes to stimulate will become clearer when there has been time to work out subject groupings under the umbrella of the federation, and there should be some progress to this end at the Geneva meeting. It will be a great surprise if Professor G. Bernadini, who has provided much of the impetus for the European Physical Society during the past two years, does not emerge in a prominent position among the officers.

\section{NAVAL ARCHITECTURE}

\section{Brunel's Great Britain}

A CAMPAIGN was opened last week for funds to refloat the Great Britain, one of the three major ships designed by Brunel. The object is to tow her back from the Falkland Islands to the Bristol shipyard where she was launched in 1843. The Great Britain was the first ocean-going iron ship and the first to be driven by propeller.

Since the late $1880 \mathrm{~s}$, the Great Britain has been moored in the Falkland Islands, and now lies rusting on a sand-bank in Sparrow Cove, near Port Stanley. Attention was drawn to the ship's historic and engineering importance by Dr Euan Corlett, a practising naval architect, in a letter to The Times last year, and has led to the setting up of a committee for the retrieval and restoration of the ship. The costs of making minor repairs to the hulk and towing her some 7,000 miles are estimated at $£ 150,000$. Back in place at the

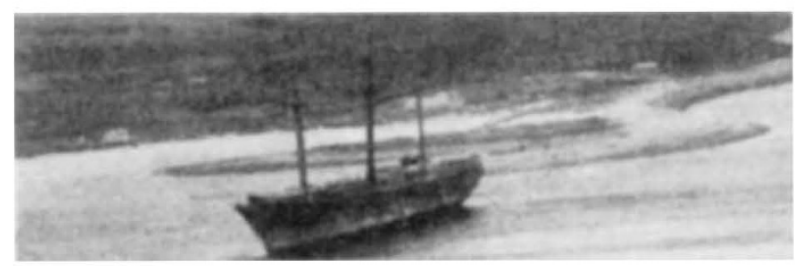

Jefferies Dock in Bristol, the substantial cost of restoration is expected to be defrayed by volunteer labour.

The first of Brunel's ships, the Great Western, was paddle-driven and built of wood. The Great Britain, besides its iron construction and propellers, incorporated revolutionary features such as the bolted rudder post which relieved pressure on the rudder and is standard design in most modern vessels. Brunel's third ship, the Great Eastern, had a double skin, a feature which other designers ignored until the sinking of the Titanic some fifty years later.

The history of the Great Britain was closely linked with that of the British Empire. The ship was the forerunner of the iron merchant vessels and battleships which in the latter half of the nineteenth century gave Britain her mercantile and naval supremacy. Brunel intended the ship to carry passengers of the Great Western Railway, of which he was a director, to New York, but the Great Britain made only a few transatlantic voyages before running aground in Dundrum Bay in Ireland. Brunel managed to refloat the ship, which for the next 20 years carried emigrants to Australia. She was withdrawn from this service to be used as a troopship in the Crimean War and during the Indian Mutiny.

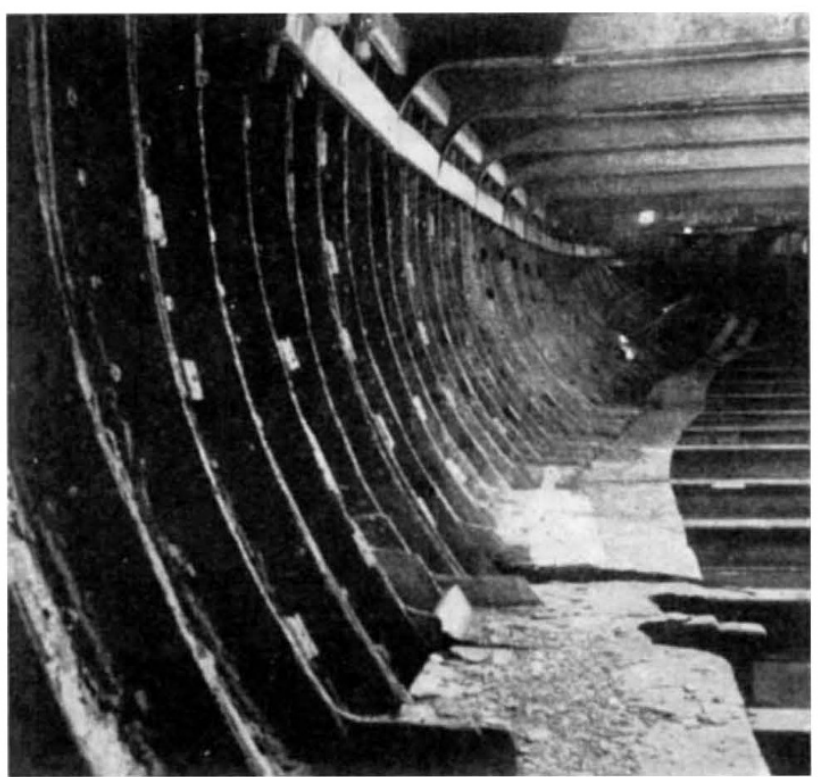

The interior of the Great Britain

In 1875, the Great Britain's engines were removed and she was converted to sail, plying between Liverpool and San Francisco until put out of service by a fire near the Falkland Islands. Her final duty was to serve as a floating warehouse. Despite the ship's age, her structure is still sound enough to survive the journey back to Britain, should the necessary funds be raised.

\section{DISEASE}

\section{Leprosy af Bay}

\section{bf our Social Medicine Correspondent}

MORE than five hundred people from seventy countries are attending the ninth International Leprosy Congress at Imperial College in London this week. The last conference was held five years ago in Rio de Janeiro. Among the topics to be discussed are the clinical and neurological aspects of leprosy, and its chemotherapy. But the subject which has advanced the most rapidly in recent years and which is likely to be the highlight of the congress is the successful experimental transmission of the disease to animals.

Failure to grow and propagate the bacterium (Mycobacterium leprae) in non-human tissues has, until recently, been one of the chief setbacks in the fight against leprosy. The significance of the developments in transmission is that the susceptibility of the organism to chemotherapeutic agents can in future be studied without endangering human life. Though effective chemotherapeutic agents are obviously desirable-and 